\title{
THE LIMITATIONS OF TRANSFORMATIONAL LEADERSHIP Trish Chaplin-Cheyne
}

\section{Preamble}

This literature review contributed in part to the author's Masters studies, with the aim of providing a critical review of transformational leadership - the preferred leadership mode in educational contexts.

\section{INTRODUCTION}

The original concept of transformational leadership was introduced in 1978 by James Macgregor Burns as a result of his research on political leaders (Lai, 20II; Sun \& Henderson, 2017). Burns argued that transformational leaders look beyond themselves and towards organisational goals, while motivating their followers (subordinates) to perform above and beyond expectation, resulting in positive outcomes for team processes and performance (Eisenberg et al., 2019; Hay, 2006; Lai, 20II; Reza, 2019; Sun \& Henderson, 2017). Eisenberg et al. (2019) described this model as the most desirable leadership style through its ability to be the "driver of change and creativity" (p. 35I).

Interest in transformational leadership has grown over the past three decades, in part due to its use in organisational psychology and management (Hay, 2006; Odumeru \& Ifeanyi, 20I3). Modification of the original theory involves four factors, known as the Four l's: idealised influence (II), inspirational motivation (IM), intellectual stimulation (IS) and individualised consideration (IC) (Alatawi, 2017; Bass, 1999; Dionne et al., 2004; Hay, 2006; Kark et al., 2003; Katene, 2010; Reza, 2019; Sun \& Henderson, 2017). The Four l's have emerged as a means of quantitatively assessing transformational leadership, as they provide a measure of the guidance provided by a given leader and a gauge for the level of responsiveness from their followers (Bass, 1999; Reza, 2019).

Most authors agree on the positive impacts that transformational leaders have on their followers, including self-efficacy and the inculcation of attitudes and values (Abdulrahman \& Amoush, 2020; Hay, 2006; Popper et al., 2000; Shepherd, 2017); however, others warn of boundaries to its effectiveness (Alatawi, 2017; Eisenberg et al., 2019; Hay, 2006).

The objective of this literature review is to explore the limitations associated with transformational leadership theory in educational settings. This review will examine the impact of situational or contextual factors, such as geographical dispersion and cultural values, on the effectiveness of transformational leadership, and will also discuss the impact of gender on leadership and explore whether gender determines a particular leadership style. 


\section{REVIEW OF THE LITERATURE}

\section{Limitations on transformational leadership - situational and contextual factors}

Transformational leaders draw on motivating values such as justice and equality to inspire, empower and transform (Foster, 1989, Kark et al., 2003; Popper et al., 2000), as opposed to transactional leaders who influence behaviours through "conventional values such as honesty and loyalty" (Popper et al., 2000, p. 269). However, a key criticism of transformational leadership is the potential for power to be abused when motivation lacks moral responsibility (Hay, 2006). Hay (2006) argues that transformational leaders must assume moral responsibility to "avoid dictatorship and oppression of a minority by a majority" (p. 10). There is a risk that followers may develop an interdependent relationship with the leader and be encouraged to go beyond personal values in the interests of the organisation, possibly resulting in negative emotional responses (Eisenberg et al., 2019; Hay, 2006; Kark et al., 2003). What is not yet fully understood from the literature, and requires further investigation, are the effects that this interdependence has on individuals, and the impact that it might have on the group as a whole.

While the Four l's represent the four elements of transformational leadership, there is some debate as to how effectively they characterise this leadership style (Alatawi, 2017). Alatawi's (2017) study "proposes [that the Four l's] are not unique to transformational leadership" (p. 22), and that they may not fully characterise the influence of the transformational model due to correlations with other leadership styles, such as transactional (leaders retain most of the power and motivate other adults solely through the use of rewards or punishments) and laissez-faire (referred to as hands-off leadership). Pounder and Coleman (2002) state that transformational leadership builds on transactional leadership and that qualities derived from both models can be employed "at one and the same time" (p. 123). While the literature informs us that there is an association between these leadership styles, it is not clear where this association begins or ends, or how leaders utilise a blend of both. Another limitation is the paucity of theoretical evidence presented by researchers that would allow us to distinguish between the four factors, and little evidence for what leaders say or do to influence followers in relation to the Four l's (Alatawi, 2017; Pounder \& Coleman, 2002).

Eisenberg et al.'s (2019) empirical study of 53 innovation teams assessed the relationship between geographically dispersed teams and team performance. They found that transformational leadership is less effective at improving performance when teams are dispersed. This is a result of team members doubting a leader's authenticity due to an inability to establish personal relationships with the leader. The researchers found that a leader's influence on communication decreases as geographical dispersion increases, resulting in lower team performance. According to the literature, in order to mitigate this limitation, the leader must consider alternative methods of providing direction and also monitor team communication among dispersed members. What the literature lacks are clear descriptions of these approaches or methods.

Another limitation on the effectiveness of transformational leadership relates to cultural ideals. Hay (2006) finds weaker links between people with "traditional cultural values" (p. 10) and leader effectiveness. Using an example from te ao Māori, Katene (20I0) describes traditional leadership as multi-dimensional, where overlapping roles and responsibilities are shared among iwi, and originally based on transactional leadership values. In the nineteenth century, transformational leadership was utilised to deal with the impact of colonisation and to meet future needs of Māori (Katene, 20I0). Katene argues that to be effective, the leader must be committed to social justice and there must be a focus "on the vision, rather than the leader" (p. 13). While the literature on leadership is extensive, there has been little research into Māori leadership, despite Katene's work.

In summary, while transformational leadership has been described as the more effective form of leadership (Hay, 2006; Reza, 2019) and has been lauded for its ability to transform organisations as well as employees, there remain limits to its effectiveness. The assumption that, as a result of innate processes and behaviours, transformational leadership theory can be applied in any context is incorrect and fails to consider situational influence. Eisenberg et al. (2019) discuss the importance of authentic transformational leadership on geographically dispersed teams; 
Hay (2006) and Katene (2010) argue that effective transformational leadership is dependent on cultural values; and Hay (2006), Eisenberg et al. (2019) and Kark et al. (2003) all warn of the potential for leaders to abuse power. It is evident that further research is required into how situational or contextual factors impact transformational leadership, and whether these factors alter depending on the gender of the leader.

\section{The gender gap in transformational leadership}

There is a significant imbalance between male and female leaders in higher education that belies statistics showing higher numbers of women in education overall (Pounder and Coleman, 2002; Shepherd, 2017). On average, women account for less than 40 percent of leadership positions worldwide; this imbalance has the potential to impact women in leadership positions in all organisational areas in the future (Abdulrahman \& Amoush, 2020; Lai, 20II). While these figures describe an unsurprising phenomenon, this situation should be mitigated in the future due to increasing numbers of women in employment and various initiatives aimed at increasing the numbers of women in leadership roles (Abdulrahman \& Amoush, 2020; Shepherd, 2017).

While the literature (Blackmore \& Sachs, 2007; Lai, 20II; Pounder \& Coleman, 2002) tells us that there are differences in how males and females approach leadership, does gender determine a leadership style, or does this put us in danger of stereotyping? Women leaders are positioned to function simultaneously in domestic roles and in educational leadership, given that there is an expectation that they are to lead, to elicit change and manage organisational "housework" (Blackmore \& Sachs, 2007, p. 15). This dual role has been described as an extension of a women's maternal instincts that include sharing, caring, relationship-building and emotional intelligence, attributes which have been collectively labelled as "what women are good at" (Blackmore \& Sachs, 2007, p. 19). These 'feminine' characteristics have been found to positively influence a women's approach to leadership, addressing the many challenges associated with the traditional masculine autocratic leadership style (Abdulrahman \& Amoush, 2020; Pounder \& Coleman, 2002).

Women leaders tend to be more democratic; they typically develop unique relationships with individuals, foster collaboration, build consensual processes and are more likely to model practice and set examples, thus minimising the potential for power abuse (Bass, 1999; Kark et al., 2003; Kouzes \& Posner, 2003; Lai, 201I; Pounder \& Coleman, 2002). Feminine leadership has been described in terms of "not knowing the answers to everything," or being leader-focussed; in this way, it is less transactional and more transformational (Lai, 20II). The leadership literature argues that transformational leadership is dependent on building relationships, inspiring and developing others and emphasising the team approach - all of which are characteristics that are conventionally associated with femininity (Bass, 1999; Lai, 2011; Pounder \& Coleman, 2002). This begs the question: Are women better leaders than men?

Women are seen as role models, and research shows that this has a positive effect on female learner retention (Abdulrahman \& Amoush, 2020). Female leadership encourages greater diversity in recruitment and the development of employees, factors aligned with organisational success (Abdulrahman \& Amoush, 2020). Lai (20II) suggests that female leaders enjoy a slight edge in performance over their male colleagues, due in part to a tendency toward a transformational leadership style. It is noteworthy that while there is obvious organisational advantage to having women in leadership positions, there remains a disincentive to women in senior management, where men are seen to be more capable (Lai, 20II; Shepherd, 2017).

This leads us to consider why women are underrepresented in leadership. We know that it is not about capability or ambition; rather, it appears to be the result of limited opportunities compared to the possibilities available to male colleagues, which suggests systemic gender bias (Blackmore \& Sachs, 2007). Studies in schools (Blackmore \& Sachs, 2007) and industry (Kark et al., 2003) have shown that males consider that women are treated equally; however, women do not agree with this assessment. There is a tension between how women see themselves and how they are seen by others. It appears that this perception of representation, coupled with women's leadership style, is highly gendered. 
Analysing early research in her doctoral study, Shepherd (2017) refers to empirical data showing that female academics were less likely to apply for leadership roles in education without support or encouragement from others. Abdulrahman and Amoush (2020) take this a step further and argue women are limited from participating in senior leadership positions. This may be related to role incongruity between female and male leaders. Women in leadership positions are under pressure to meet the expectations of traditional leadership styles which exhibit the masculine characteristics of assertiveness, forcefully expressing disagreement, ambition, reward-seeking, and a readiness to hand out punishment (Blackmore \& Sachs, 2007; Lai, 20II). However, if women demonstrate these dominant behaviours, they will be met with greater disapproval and rejection than would be the case for their male counterparts (Lai, 20II).

In summary, although the discrepancies in the positioning of women in educational leadership reflect gender differences and gender bias in leadership styles, there is little evidence to prove that gender determines a leadership style (Blackmore \& Sachs, 2007; Lai, 20II). What has become increasingly obvious is gender stereotyping. Males do not have to prove leadership competency in the same way that women do, and men are seen as naturally "more capable of being leaders" (Lai, 20II, p. 5) - a position which is consistent with gender-based stereotyping.

\section{CONCLUSION}

Transformational leadership is rated highly by researchers in the field because of leaders' ability to empower their followers due to the creation of a shared vision. However, this theory does have its weaknesses, and the impact of situational or contextual factors cannot be ignored. One contextual factor in particular - women versus males in educational management - was explored in depth. However, questions still remain. Future studies should examine the similarities and differences between transformational leadership and other leadership styles to investigate how the weaknesses identified here can be minimised. Perhaps a modified theory would better meet the needs of all genders across all levels of leadership in education.

Trish Chaplin-Cheyne is the director of Learning and Teaching Development at Otago Polytechnic, where she is responsible for the learning and teaching development service team. This team is tasked with ensuring that Otago Polytechnic programmes and courses are designed to best practice standards; that academic staff have the full range of knowledge and skills needed to facilitate learner success; and that learners enjoy an outstanding experience with Otago Polytechnic. She is involved with facilitating on the Graduate Diploma in Tertiary Education and enjoys being in the classroom environment. Trish joined Otago Polytechnic in 2015, as a learning facilitator involved in the Designing for Learner Success initiative. Her areas of particular interest are curriculum and assessment design. (10) https://orcid.org/0000-0002-2709-572X 


\section{REFERENCES}

Abdulrahman, M., \& Amoush, A. (2020). Female characteristics and their new roles in leadership. Journal of Business and Management Sciences, 8(2), 38-47. https://doi.org/I0.1269|/jbms-8-2-I

Alatawi, M. A. (2017). The myth of the additive effect of the transformational leadership model. Contemporary Management Research, 13(1), 19-30. https://doi.org//0.7903/cmr.16269

Bass, B. M. (1999). Two decades of research and development in transformational leadership. European Journal of Work and Organizational Psychology, 8(I), 9-32. https://doi.org/I0.1080/I359432993984I0

Blackmore, J., \& Sachs, J. (2007). Performing and reforming leaders. gender, educational, restructuring, and organizational change. State University of New York Press.

Clarkin-Phillips, J. (2017). When the odds are stacked against: Leadership decisions that shift the odds. In R. McNae, M. Morrison \& R. Notman (Eds.), Educational leadership in Aotearoa New Zealand: Issues of context and social justice (pp. 105-1I7). NZCER Press

Dionne, S. D., Yammarino, F. J., Atwater, L. E., \& Spangler, W. D. (2004). Transformational leadership and team performance. Journal of Organizational Change Management, 17(2), 177-193. https://doi.org//0.1108/0953481041053060।

Eisenberg, J., Post, C., \& DiTomaso, N. (2019). Team dispersion and performance: The role of team communication and transformational leadership. Small Group Research, 50(3), 348-380. https://doi.org/l0.1177/1046496419827376

Foster, W. (1989). Toward a critical practice of leadership. In S. Smyth (Ed.), Critical perspectives on educational leadership (2nd ed., pp. 27-42). Routledge Falmer.

Hay, I. (2006). Transformational leadership: Characteristics and criticisms. E-Journal of Organizational Learning and Leadership, 5(2). http://www.weleadinlearning.org/ejournal.htm

Kark, R., Shamir, B., \& Chen, G. (2003). The two faces of transformational leadership: Empowerment and dependency. Journal of Applied Psychology, 88(2), 246-255. https://doi.org/I0.1037/0021-9010.88.2.246

Katene, S. (2010). Modelling Māori leadership: What makes for good leadership? MAI Review, 2, I-16. https://www.researchgate. net/publication/46146419_Modelling_Maori_Leadership_What_Makes_for_Good_Leadership

Kouzes, J. M., \& Posner, B. Z. (2003). The five practices of exemplary leadership. https://www.pnbhs.school.nz/wp-content/ uploads/2015/II/The-Five-Practices-of-Exemplary-Leadership.pdf

Lai, A. (20II). Transformational-transactional leadership theory. 20II AHS Capstone Projects. Paper 17. http://digitalcommons.olin. edu/ahs_capstone_2011/17

Odumeru, J. A., \& Ifeanyi, G. O. (2013). Transformational vs. transactional leadership theories: Evidence in literature. International Review of Management and Business Research, 2(2), 355-361.

Pataka, P. (20II). Cultural change and moral leadership. In R. Notman (Ed.), Successful educational leadership in New Zealand: Case studies of schools and an early childhood centre (pp. III-122). NZCER Press.

Popper, M., Mayseless, O., \& Castelnovo, O. (2000). Transformational leadership and attachment. The Leadership Quarterly, I/(2), 267-289. https://doi.org/10.1016/SI048-9843(00)00038-2

Pounder, J. S., \& Coleman, M. (2002). Women - Better leaders than men? In general and educational management it still "all depends." Leadership \& Organization Development Journal, 23(3), 122-133. https://doi.org/I0.1 I08/01437730210424066

Reza, M. H. (2019). Components of transformational leadership behaviour. EPRA Internal Journal of Multidisciplinary Research, 5(3), 119-124.

Shepherd, S. (2017). Why are there so few female leaders in higher education: A case of structure or agency? Management in Education, 3/(2), 82-87. https://doi.org/l0.1177/0892020617696631

Sun, R., \& Henderson, A. C. (2017). Transformational leadership and organizational processes: Influencing public performance. Public Administration Review, 77(4), 554-565. https://doi.org/I0.1 III/puar. 12654 